\title{
MENUMBUHKAN JIWA WIRAUSAHA SISWA DAN GURU SEKOLAH MENENGAH KEJURUAN (SMK) PGRI PEKANBARU MELALUI PELATIHAN PEMBUATAN SABUN CUCI PIRING CAIR
}

\author{
Ranti Darwin*, Dwi Widiarsih, Neng Murialti, Muhammad Hidayat, \\ M.Fikry Hadi, Mizan Asnawi \\ Prodi Ekonomi Pembangunan, Fakultas Ekonomi dan Bisnis \\ Universitas Muhammadiyah Riau \\ email: ranti.darwin@umri.ac.id
}

\begin{abstract}
One part of the development of Higher Education activities other than educational institutions that have the main tasks and teaching process, as well as the implementation of research and community service. Community service is an activity related to improving the quality and productivity of society. Implementation of community service activities is expected to realize a better society.The forms of community service undertaken by the Faculty of Economics Lecturer one of the Economic Development Studies program is to provide skills to students who can be accepted by teachers in Vocational High School PGRI Pekanbaru which is located at Jl. Brig. Gen. Katamso No.46 Bukit Raya Kota Pekanbaru, in the form of making dishwashing liquid soap. After the training is expected, students and teachers can develop creativity in creating products that have a selling value and have a strong entrepreneurship spirit.
\end{abstract}

Keywords: Entrepreneur, Dishwashing Liquid Soap, Increased Income

\begin{abstract}
Abstrak
Salah satu bagian dari pengembangan kegiatan Perguruan Tinggi selain sebagai lembaga pendidikan yang memiliki tugas pokok melaksanakan proses pendidikan dan pengajaran, juga melaksanakan penelitian dan pengabdian pada masyarakat. Pengabdian pada masyarakat adalah suatu kegiatan yang berhubungan dengan peningkatan kualitas dan produktivitas masyarakat. Pelaksanaan kegiatan pengabdian masyarakat diharapkan dapat mewujudkan masyarakat yang lebih baik. Adapun bentuk pengabdian masyarakat yang dilakukan oleh Dosen Fakultas Ekonomi salah satunya Program Studi Ekonomi Pembangunan adalah memberikan keterampilan kepada siswa siswi beserta guru-guru di Sekolah Menengah Kejuruan (SMK) PGRI Pekanbaru yang beralamat di Jl. Brigjen Katamso No.46 Bukit Raya Kota Pekanbaru, dalam bentuk pembuatan sabun cuci piring cair. Setelah diadakan pelatihan diharapkan siswa dan guru dapat mengembangkan kreatifitas dalam menciptakan produk yang memiliki nilai jual dan memiliki jiwa entrepreneurship yang tangguh.
\end{abstract}

Kata kunci: Enterpreneur, Sabun Cuci Piring Cair, Peningkatan Pendapatan 


\section{PENDAHULUAN}

Kebersihan menjadi satu hal yang penting dalam kehidupan. Salah satu alat untuk penunjang kebersihan itu adalah sabun. Penggunaan sabun sudah tidak asing lagi dalam kehidupan sehari-hari. Pada perkembangannya seperti sekarang, semakin banyak jenis sabun yang beredar di pasaran, mulai dari yang bersifat khusus untuk kecantikan maupun umum untuk membersihkan kotoran salah satunya adalah sabun cuci piring. Sabun cuci piring mempunyai dua bentuk, yaitu sabun cuci piring cream dan sabun cuci piring cair. Faktor kepraktisan dan kecepatan larut sabun dalam air pada sabun cair menyebabkan banyak orang lebih memilih menggunakannya daripada sabun cream cuci piring. Selain itu pula disebabkan aroma sabun cream baunya lebih menempel pada peralatan dapur serta kurang lembut di tangan. Oleh karena itu diperlukannya produk yang lebih ramah lingkungan salah satunya sabun cair untuk pencuci piring.

Sabun secara umum merupakan senyawa natrium atau kalium yang mempunyai rangkaian karbon yang panjang dan direaksikan dengan asam lemak khususnya trigliserida dari minyak nabati atau lemak hewani. Sabun dihasilkan oleh proses saponifikasi, yaitu hidrolisis lemak menjadi asam lemak dan gliserol dalam kondisi basa. Pada perkembangannya bentuk sabun menjadi bermacammacam, yaitu sabun padat, sabun lunak, sabun cair, dan sabun bubuk.

Melihat besarnya manfaat penggunaan sabun pencuci piring ini, maka ini menjadi suatu peluang yang bisa dijadikan salah satu produk dalam menumbuh kembangkan suatu wirausaha. Kegiatan wirausaha ini tentunya tidak terlepas dari adanya semangat kewirausahaan bagi calon entrepreneurship ini. Semangat kewirausahaan dapat dimiliki oleh semua orang, begitu juga dengan para siswa dan guru di SMK PGRI Pekanbaru. Para siswa dapat melatih kemampuan entrepreneur yang mereka miliki dengan menciptakan inovasiinovasi produk yang berkualitas. Salah satu upaya untuk menciptakan semangat kewiruasahaan siswa dan guru SMK ini, khususnya siswa dan guru SMK PGRI Pekanbaru yaitu dengan membuat pelatihan sabun cuci piring cair.

Kegiatan pembuatan sabun cuci piring cair ini diharapkan dapat memberikan manfaat kepada siswa dan guru SMK PGRI Pekanbaru untuk dapat meningkatkan kreatifitasnya. Pelatihan ini akan dapat memberikan manfaat bagi para siswa dan guru untuk menyadari bahwa pentingnya melatih jiwa kewirausahaan dalam diri mereka. Selain itu kegiatan ini dapat memanfaatkan waktu luang siswa dan guru untuk mengadakan kegiatan yang produktif dan tidak tertutup kemungkinan akan dapat menambah penghasilan sampingan para siswa dan guru. Pembuatan sabun cuci piring cair ini akan dapat menjadi salah satu kegiatan yang akan mendatangkan manfaat dalam memudahkan mencuci piring bagi setiap orang yang membutuhkannya. Sabun cuci piring cair ini tidak hanya dapat dimanfaatkan oleh ibu-ibu rumah tangga, namun juga akan digunakan salah satunya oleh pihak Rumah Makan, Cafe, dll.

Sabun cuci piring cair ini dapat menjadi salah satu produk yang memiliki nilai guna yang tinggi dan juga memiliki prospek pasar yang bagus. Ini bisa menjadi suatu peluang yang dapat dimanfaatkan oleh siswa dan guru SMK PGRI Pekanbaru. Hal ini tentunya menuntut adanya kreativitas dan inovasi bagi siswa dan 
guru SMK ini untuk dapat menciptakan sabun cuci piring cair yang berkualitas dan salah satu langkah awal mereka dalam melatih jiwa wirausaha yang ada dalam diri mereka.

\section{Rumusan Masalah}

Berdasarkan penjelasan yang terdapat pada latar belakang dapat diketahui beberapa permasalahan yaitu bagaimana cara menumbuhkan jiwa wirausaha dengan cara mengadakan pelatihan pembuatan sabun cuci piring cair.

\section{Tujuan}

Tujuan dari pengabdian masyarakat ini adalah : memberikan pengetahuan tentang menumbuh kembangkan jiwa kewirausahaan siswa dan guru melalui pembuatan sabun cuci piring cair.

\section{Manfaat}

Dengan dilaksanakannya pengabdian masyarakat ini maka diharapkan para siswa dan guru dapat mengembangkan kreativitas dan mendorong semangat entrepreneur untuk meningkatkan pengahasilan tambahan bagi bagi para siswa dan guru.

\section{METODE PENGABDIAN}

Koordinasi dan dukungan berbagai pihak dalam pelaksanaan kegiatan pengabdian kepada masyarakat ini sangat memberikan manfaat yang besar bagi kelancaran pelaksanaan kegiatan pengabdian ini. Kerjasama yang baik antara pihak sekolah yaitu SMK PGRI Pekanbaru yang akan menjadi peserta pengabdian dengan tim pelaksana kegiatan merupakan salah satu faktor penentu keberhasilan kegiatan pengabdian ini. Sebelum memulai kegiatan pengadian ini, tim pengabdian melakukan survey awal ke lokasi yaitu SMK PGRI Pekanbaru tempat pengabdian akan berlangsung dan berkoordinasi dengan pihak sekolah.

Kegiatan pengabdian pada masyarakat di laksanakan dengan metode ceramah, demonstrasi/ pelatihan dan tanya jawab yang dilaksanakan selama 1 (satu) hari. Adapun tahapan-tahapan dalam pelaksanaan kegiatannya adalah sebagai berikut : Ceramah digunakan untuk penyampaikan pengetahuan secara umum tentang manfaat berwirausaha, peluang wirausaha dan langkah-langkah untuk menjadi seorang wirausaha yang sukses.

Demonstrasi digunakan untuk memberikan keterampilan secara langsung mengenai proses pembuatan sabun cuci piring cair yang nantinya akan disampaikan oleh instruktur yang ada. Pelatihan pembuatan sabun cuci piring cair ditujukan untuk memberikan pengetahuan kepada para siswa dan guru untuk menumbuhkan jiwa wirausaha para siswa dan guru, dan membangkitkan semangat mereka untuk memulai usaha salah satunya melalui pembuatan produk sabun cuci piring cair ini.

Evaluasi hasil pelatihan dilakukan selama proses dan setelah kegiatan pelatihan dilaksanakan. Evaluasi ini ditujukan untuk perbaikan di masa yang akan datang, untuk menjadikan kegiatan pengabdian kepada masyarakat ini menjadi salah satu kegiatan memberikan manfaat yang besar baik bagi masyarakat maupun bagi dosen sebagai penyelenggara kegiatan ini.

Sabun adalah surfaktan yang digunakan dengan air untuk mencuci dan membersihkan. Sabun biasanya berbentuk padatan tercetak yang disebut batang karena sejarah dan bentuk umumnya. Penggunaan sabun cair juga telah telah meluas, terutama pada sarana-sarana publik. Jika diterapkan pada suatu permukaan, air bersabun secara efektif mengikat partikel dalam suspensi mudah dibawa oleh air bersih. Di negara 
berkembang, deterjen sintetik telah menggantikan sabun sebagai alat bantu mencuci atau membersihkan (Anonim, 2012). Sabun ini merupakan logam alkali dengan rantai asam monocarboxylic yang panjang. Larutan alkali yang biasa digunakan pada sabun batang adalah $\mathrm{NaOH}$ sedangkan untuk sabun cair adalah $\mathrm{KOH}$.

Sabun juga merupakan suatu gliserida (umumnya $\mathrm{C}_{16}$ dan $\mathrm{C}_{18}$ atau karboksilat) yang merupakan hasil reaksi antara ester (suatu derivat asam alkanoat yaitu reaksi antara asam karboksilat dengan alkanol yang merupakan senyawa aromatik dan bermuatan netral) dengan hidroksil dengan residu gliserol (1.2.3 propanatriol). Apabila gliserol bereaksi dengan asam-asam yang jenuh (suatu olefinatau polyunsaturat) maka akan terbentuk lipida (trigliserida atau triasilgliserol) (Atmojo, 2012). Sabun merupakan bahan logam alkali (basa) dengan rantai asam monocarboxylic yang panjang. Larutan alkali yang digunakan dalam pembuatan sabun bergantung pada jenis sabun tersebut. Larutan alkali yang biasa digunakan pada sabun keras adalah Natrium Hidroksida $(\mathrm{NaOH})$ dan alkali yang biasa digunakn pada sabun lunak adalah Kalium Hidroksida (KOH).

Sabun adalah surfaktan yang digunakan dengan air untuk mencuci dan membersihkan. Sabun biasanya berbentuk padatan tercetak yang disebut batang karena sejarah dan bentuk umumnya. Penggunaan sabun cair juga telah telah meluas, terutama pada sarana-sarana publik. Jika diterapkan pada suatu permukaan, air bersabun secara efektif mengikat partikel dalam suspensi mudah dibawa oleh air bersih. Di negara berkembang, deterjen sintetik telah menggantikan sabun sebagai alat bantu mencuci atau membersihkan (Anonim,
2012). Sabun ini merupakan logam alkali dengan rantai asam monocarboxylic yang panjang. Larutan alkali yang biasa digunakan pada sabun batang adalah $\mathrm{NaOH}$ sedangkan untuk sabun cair adalah $\mathrm{KOH}$.

Jiwa kewirausahaan yaitu merupakan nyawa kehidupan dalam kewirusahaan yang pada dasarnya merupakan sikap dan perilaku kewirausahaan yang ditunjukan melalui sifat, karakter, dan watak seseorang yang memiliki kemauan dalam mewujudkan gagasan inovatif ke dalam dunia nyata secara kreatif (Purnomo, 2005).

Menjadi wirausaha yang berhasil adalah impian setiap pelaku usaha, dan persyaratan utama yang harus dimilikinya adalah jiwa dan watak kewirausahaan. Jiwa dan watak kewirausahaan tersebut dipengaruhi oleh keterampilan, kemampuan, atau kompetensi. Kompetensi itu sendiri ditentukan oleh pengetahuan dan pengalaman usaha. Seorang wirausaha adalah seseorang yang memiliki jiwa dan kemampuan tertentu dalam berkreasi dan berinovasi. Ia adalah seseorang yang memiliki kemampuan untuk menciptakan sesuatu yang baru dan berbeda (ability to create the new and different). Kemampuan kreatif dan inovatif tersebut secara riil tercermin dalam kemampuan dan kemauan untuk memulai usaha (start up), kemampuan untuk mengerjakan sesuatu yang baru (creative), kemauan dan kemampuan untuk mencari peluang (opportunity), kemampuan dan keberanian untuk menanggung risiko (risk bearing) dan kemampuan untuk mengembangkan ide dan meramu sumber daya (Purhantara, 2013).

\section{HASIL DAN PEMBAHASAN}

Pelaksanaan kegiatan pegabdian kepada masyarakat ini telah terlaksana 
dengan baik. Kegiatan penagabdian kepada masyarakat ini telah dilaksanakan di Sekolah Menengah Kejuruan (SMK) PGRI Pekanbaru yang beralamat di J1. Brigjen Katamso No.46 Bukit Raya Kota Pekanbaru. Tim pelaksana dari Program Studi Ekonomi Pembangunan, Fakultas Ekonomi dan Bisnis, Universitas Muhammadiyah Riau mendapatkan sambutan yang sangat baik dari pihak tempat pelaksana kegiatan yaitu SMK PGRI Pekanbaru.

Terlaksananya

kegiatan pengabdian kepada masyarakat ini sesuai dengan jadwal yang telah ditetapkan dan disepakati oleh SMK PGRI Pekanbaru sebelum kegiatan ini dilaksanakan. Pengabdian kepada masyarakat ini telah melalui beberapa tahapan. Tahapan pertama dimulai dengan melakukan tahap persiapan, pada tahapan ini dimulai dengan mempersiapkan proposal kegiatan pengabdian pada masyarakat, selanjutnya dilakukan observasi dan permohonan izin kepada pihak sekolah SMK PGRI Pekanbaru sebagai tempat pelaksanaan pengabdian ini. Disamping itu juga mengumpulkan informasi mengenai jumlah peserta yaitu jumlah siswa dan guru SMK PGRI Pekanbaru yang akan mengikuti pelatihan pembuatan sabun cair ini.

Setelah waktu pelaksanaan kegiatan disepakati, tahapan berikutnya tim dari Dosen Fakultas Ekonomi dan Bisnis menyusun jadwal pelaksanaan dan membuat kesepakan dengan pihak Sekolah Menengah Kejuruan (SMK) PGRI Pekanbaru) mengenai prosedur dan langkah-langkah pelaksanaan kegiatan pelatihan pembuatan sabun cuci cair. Pihak pelaksana segera melengkapi segala atribut untuk penunjang kelancaran pengabdian ini. Keberlangsungan kegiatan pengabdian ini juga melibatkan mahasiswa dari Program Studi Ekonomi Pembangunan.

Tujuan dari kegiatan pelatihan ini dilaksanakan adalah dalam rangka pelaksanaan Catur Dharma Perguruan Tinggi Muhammadiyah, yang salah satunya adalah pengabdian pada masyarakat. Pelatihan ini ditujukan kepada siswa dan guru-guru di Sekolah Menengah Kejuruan (SMK) PGRI Pekanbaru, adapun bentuk pelatihan berupa kiat pembuatan sabun cuci piring cair bagi peningkatan produktivitas jiwa entrepreneur pada siswa dan guru-guru sekolah SMK PGRI Pekanbaru. Melalui kegiatan pelatihan ini akan dapat menciptakan kreativitas dan keterampilan siswa dan guru SMK PGRI Pekanbaru dalam pemanfaatan waktu luang untuk menghasilkan produk yang menghasilkan nilai jual. Kemampuan siswa dan guru dalam menciptakan sabun cuci piring cair diharapkan dapat menghasilkan pendapatan tambahan bagi para siswa dan guru.

Pada tahap kedua, merupakan tahap pelaksanaan kegiatan. Sebelum melakasanakan tahapan pelaksanaan, tim pelaksana melaksanakan tahap persiapan dengan melakukan briefing untuk penyiapan bahan- bahan yang dibutuhkan pada saat pelatihan, selain itu juga membagi job descreption masing - masing pembicara, menyiapkan para peserta pelatihan, menyiapkan materi pelatihan yang berhubungan dengan peningkatan jiwa wirausaha dan materi pelatihan pembuatan sabun cuci piring cair.

Tahapan pelaksanaan kegiatan dilaksanakan sesuai dengan waktu yang telah di sepakati pada tanggal 21 Februari 2018 bertempat di aula Sekolah Menengah Kejuruan (SMK) PGRI Pekanbaru. Tahapan pelaksanaan kegiatan dimulai dengan menjelaskan materi tentang kewirausahaan, makna 
dari kewirausahaan, langkah dan tahapan menjadi seorang wirausaha, manfaat dari berwirausaha, dan peluang-peluang usaha untuk memotivasi peserta dalam pemanfaatan waktu luang untk mencipatakan produk sabun cuci pring cair yang bernilai ekonomi bagi peningkatan produktivitas jiwa entrepreneur. Tahapan pelaksanan selanjutnya yaitu demonstrasi pembuatan sabun cuci piring cair secara langsung.

Tahapan pelatihan diberikan kepada setiap peserta berupa uraian atau langkah-langkah pembuatan produk sabun cuci piring cair dengan menggunakan alat dan bahan yag telah disiapkan sebelumnya. Perserta diberi kesempatan untuk melakukan tanya jawab dan diberikan pengarahan oleh instruktur pada saat pelatihan berlangsung, instruktur menjelaskan langkah-langkah pembuatan sabun cuci piring cair dan langsung mendemostrasikan kepada peserta pelatihan . Peserta yang membentuk lingkaran sambil dengan seksama melihat proses pembuatan sabun cuci piring cair. Peserta mengikuti langkahlangkah yang diperagakan oleh instruktur sesuai dengan bahan dan alat yang digunakan dan mempraktekan nya secara bergantian satu persatu dalam mengaduk bahan olahan sabun cuci piring cair. Pelatihan berlangsung mulai pukul $13.00-17.00 \mathrm{WIB}$.

Evaluasi pada tahap pertama telah sesuai dengan indikator dan rancangan evaluasi diperoleh data bahwa jumlah peserta yang hadir sebanyak 55 orang dari 60 peserta sehingga tingkat kehadiran mencapai $92 \%$. Peserta pelatihan baik siswa dan guru sangat terlihat antusias selama mengikuti kegiatan pelatihan pembuatan sabun cuci piring cair dari awal kegiatan dimulai hingga pelatihan selesai
Peserta diberi kesempatan untuk mempraktekan secara langsung pembuatan sabun cuci piring cair satu persatu kedepan secara bergantian. Setelah dilakukan pelatihan diharapkan siswa dan guru SMK PGRI Pekanbaru dapat membuat produk berupa sabun cuci piring cair yang menambah penghasilan mereka. Selain itu, diharapkan para peserta pelatihan dapat mengembangkan produk yang memiliki daya jual yang berdaya saing.

Setelah kegiatan ini selesai dilaksanakan, maka tim pelaksana melakukan evaluasi. Adapun evaluasi dari kegiatan ini dapat dinyatakan secara umum berhasil dengan baik dan memuaskan peserta siswa dan guru SMK PGRI Pekanbaru maupun instruktur pelatihan dari kegiatan pelatihan ini sendiri. Pelatihan ini mendapatkan sambutan yang hangat dan antusias yang sangat baik dari pihak tempat terselenggaranya pelatihan ini. Mereka berharap pelatihan ini dapat dilaksanakan untuk tahun-tahun berikutnya.

\section{KESIMPULAN}

Kegiatan pengabdian kepada masyarakat berupa kegiatan pelatihan pembuatan sabun cuci piring cair yang diadakan di SMK PGRI Pekanbaru dengan pemanfaatan bahan-bahan kimia yang ramah lingkungan dan bernilai ekonomi ini secara keseluruhan dapat berjalan baik dan lancar. Pelatihan ini memberikan keterampilan wirausaha kepada siswa dan guru SMK PGRI sebagai bekal wirausaha, atau pun sebagai bekal untuk memulai usaha sampingan mereka. Pemaparan materi kewirausahaan oleh pemateri diharapkan dapat memacu semangat para siswa dan guru dalam melakukan kegiatan wirausaha salah satunya melalui penciptaan sabun cuci piring cair. 
Peningkatan dan pengembangan keterampilan oleh siswa dan guru SMK PGRI Pekanbaru akan berdampak terhadap pertumbuhan usaha rumah tangga yang nantinya mampu meningkatkan pendapatan siswa dan guru dan sekaligus dapat menciptakan lapangan usaha bagi siswa dan guru. Selain itu, kegiatan ini juga akan memberikan manfaat bagi masyarakat sekitar karena dapat menyediakan produk sabun cuci piring cair berkualitas dan bermutu yang kualitasnya sama dengan produk yang diciptakan kompetitor dengan harga yang lebih murah.

\section{UCAPAN TERIMAKASIH}

Terimakasih kami ucapkan kepada semua pihak yang mendukung kelancaran pengabdian ini terutama untuk Sekolah Menengah Kejuruan (SMK) PGRI Pekanbaru dan kepada Bapak Ibu Dosen Universitas Muhammadiyah Riau.

\section{DAFTAR PUSTAKA}

1. As'ad, M. 2002. Psikologi Industri. Yogyakarta:

Liberty. http://sinthalestari.blogspot.co.id/20 14/05/makalah-pembuatan-sabuncair.html

2. Purhantara, W. (2013). Analisis Kepemilikan Jiwa Kewirausahaan: Evaluasi Outcome Pendidikan Menengah Di Jawa. Jurnal Economia, 9(2). Retrieved from https://media.neliti.com/media/publi cations/19724-ID-analisis-

kepemilikan-jiwa-kewirausahaanevaluasi-outcome-pendidikanmenengah-di.pdf

3. Purnomo, H. Bambang .2005. Membangun Semangat Kewirausahaan. Yogyakarta: Laksbang Pressindo.

4. Machfoedz, Mas'ud. (2005).
Kewirausahaan, Metode, Manajemen dan Implementasi. Yogyakarta: BPEE Yogyakarta.

5. Ranto, Basuki. (2007). Manajemen Usahawan Indonesia No.10/TH.XXXVI Oktober. Jakarta: Bagian Publikasi Lembaga Manajemen FEUI.

6. Suryana. 2001. Konsep Kewirausahaan Dalam

Mengembangkan Ide-ide Usaha. (Online). (http:// www. blogekonomi. com) diakses 20 Juni 2016.

7. Suryana. 2009. Kewirausahaan, Pedoman Praktis: Kiat dan Proses Menuju Sukses. Jakarta: Salemba Empat.

8. Wiryowidagdo, Sumali, 2000." Kimia dan Farmakologi Bahan Alam". Universitas Indonesia : Jakarta 